E3 Journal of Agricultural Research and Development Vol. 6(3). pp. 065-069, September, 2016

Available online http://www.e3journals.org

ISSN: 2276-9897 (C) E3 Journals 2016

DOI : http://dx.doi.org/10.18685/EJARD(6)3_EJARD-16-013

\title{
Analysis of Perceived Effects of Climate Variation on Fish Farming in Rivers State, Nigeria
}

\author{
Chikaire $\mathrm{JU}^{1^{*}}$, Orusha $\mathrm{JO}^{2}$, Tim-Ashama $\mathrm{A}^{2}$, Nwarieji $\mathrm{FE}^{2}$ and Daniel-Uchegbu $\mathrm{C}^{2}$ \\ ${ }^{1}$ Dept. of Agricultural Extension, Federal University of Technology, Owerri, Imo State, Nigeria. \\ ${ }^{2}$ Dept. of Agricultural Science Education, Alvan Ikoku College of Education Owerri, Imo State, Nigeria.
}

Accepted 30 June, 2016

The study examined the effects of changing climate on fish farming in Rivers State, Nigeria. The specific objectives were to describe the socioeconomic characteristics of the fish farmers, identify observed evidence of climate change in the study area, examine perceived effects of climate change on fish farming activities and to identify the adaption strategies taken up by the respondents. Multi stage sampling technique was employed in selection of sample respondents. Data were collected through structured pretested questionnaire and by personal interview. 250 fish farmers were selected randomly from a list of 2500 fish farmers obtained from fish farmers cooperative office in Andoni, headquarters of Zone II. Data were analyzed using descriptive statistical tools such as percentages, presented in tabular forms. Majority of the fish farmers (42\%) were in the age group of 51 years and above, $81 \%$ were males, $82 \%$ were married, $36.8 \%$ had a family size of $6-10$ people. 37.6 percent sample respondents have secondary education, $43.6 \%$ had more than 21 years in fishing experience. Climate change evidence observed through the variable precipitation, intensity of sunlight, velocity of winds, frequency of flood etc. Climate changes affect fish production in many ways such as increased fish harvest, increase growth rate, increased diseases outbreak, deteriorated water quality, changes in fish harvest pattern, increased cost of production.

Keyboards: Climate change, fish farming, adaptation, temperature, Rivers state.

\section{INTRODUCTION}

Climate change has serious implications for global fisheries and aquaculture. Besides the physical and financial drivers, climate is a major driver that enhances the aquaculture sector growth and sustainability. Millions of people including many in developing countries derive their livelihoods from fishing while around 2.6 billion people across the world get their protein from seafood. Fish act as a vital source of protein to 200 million people and provide employment for upto ten million people in Africa (Adebo and Ayelari, 2011). About 30\% percent (29.5 MT) of the world fish catch is used for non-human consumption, including the production of fishmeal and fish oils that are employed in agriculture, in aquaculture,

\footnotetext{
${ }^{*}$ Corresponding authors E mail: futo.edu.ng@gmail.com
}

and for industrial purposes. Fishmeal and fish oils are key diet components for aquaculture production; depending on the species being cultured, they may constitute more than $50 \%$ of the feed. Despite the importance of fish to the World economy, reports around the World indicate vulnerability of fish production to climate change (Adebo and Ayelare, 2011).

According to Intergovernmental Panel on Climate Change (2007a), climate change could have dramatic impacts on fish production, which would affect the supply of fishmeal and fish oils and that future aquaculture production could be limited by the supply of fishmeal or fish oils if stocks of species used in the production of fishmeal are negatively affected by climate change and live-fish production. Fish farming, although over 200 years ago started in Nigeria in the early 1950's, in Panyam Plateau state, Onikan in Lagos and Umuna in 
Table 1: Agricultural Zones in Rivers State

\begin{tabular}{ccc}
\hline $\begin{array}{c}\text { Zones I - Crop Zone } \\
\text { Headquarters: Bori }\end{array}$ & $\begin{array}{c}\text { Zone II - Fishing Zone } \\
\text { Headquarters: Andoni }\end{array}$ & $\begin{array}{c}\text { Zone III - Crop/Livestock Zone } \\
\text { Headquarters: Omuma. }\end{array}$ \\
\hline Port Harcourt & Abua/Odual & Ahoada East \\
Obio/Akpor & Akuku-Toru & Ahoada West \\
Khana & Andoni & Emohua \\
Gokana & Asari-Toru & Etche \\
Oyigbo & Degema & Ikwerre \\
Tai & Wakirike & Ogba-Egbema-Ndoni \\
Eleme & Opobo/Nkoro & Omuma \\
Ogu-Bolo & Bonny & \\
\hline
\end{tabular}

Source: Rivers State Agricultural Development Programme Annual Report (2000)

Imo State.The fish yields and desired impact of these government fish farms has not been as appreciable as was intended earlier. Recently the popularization of fish farming remained largely within government circle. Several government policies attempted to improve fish farming. In 1980's the Directorate of Food, Road and Rural Infrastructure (DFRRI) introduced nationwide the homestead fish pond and hatchery construction projects. This gave rise to establishment of over 3,000 homestead fish ponds as well as hatcheries in each of the existing states of Nigeria (Satia, 1990; NEPAD, 2005,).

Fisheries is a food production system composed of habitat or water body, the fish population and the users who are mainly the fishermen. These sub-systems are intricately related and the impact of climate change on any one will affect others directly or indirectly and the people depended on them. Rivers State belongs to one of the coastal in Nigeria Delta region of the country with vast potential for fish farming (Agwu and Anyanwu 2007).

The State is characterized by various types of water bodies such as rivers, fresh and brackfish water, creeks and estuaries as well as marine water bodies. These water bodies provide great opportunities for aquaculture. Fish farming in the state is rather means of capture fisheries which is the pre-occupation of most riverine communities in the state. The need to increase food supply especially animals protein in Nigeria like in most third world countries gave rise to culture fishery activities in the state (Akinrotimi et al., 2007). In recent times, aquaculture has been identified as a rational way of augmenting the dwindling fish supply from capture fisheries (Ezenwa, 2004). This increase in acceptance could also be due to the growing demand for some fish and brackish water fish species for the supply of valuable fish protein (Akinrotimi et al., 2007).

Rivers state being a maritime state with access to the sea, the state is endowed with some major inland water bodies and their valuable resources which could be harnessed to augment capture fisheries production. The fish farmers cannot meet the fish demand of the people and that makes fish to be very expensive which also make fish as the food for the rich. The fish demand of the state is also increasing over time with the increase in population size and change in consumption habit. The present fish supply is unable to meet the demand due to low production.

This paper discusses the perception of fish farmers on the effects of climate change on fish production as well as strategies adopted to cope with the effects in Rivers State. The specific objectives were to:

$>$ describe the socio-economic characteristics of fish farmers in the state;

$>$ identify observed evidence of climate change by fish farmers;

$>$ ascertain fish farmers' perception of effects of climate change on fish production;

\section{METHODOLOGY}

This study was carried out in Rivers State of Nigeria, which is situated in the Niger Delta having topography of flat plains with a network of rivers and tributaries. These include new Calabar, Orashi, Bonny, among others. The state is divided into 3 agricultural zones as show in table 1, by the Rivers State Agricultural Development Project (RISADP). The 3 zones are made up of 23 Local Government Areas (LGAs) of Rivers State. The Fish farmers in the state constituted the population for the study. A multi-stage random sampling technique was used to select respondents. Five LGAs were purposively selected because of their natural endowment for fish production.

Two communities were selected randomly from each of the five LGAs to give a total of ten communities. Twenty five fish farmers were selected from each of the community. This gave a sample size of 250 . Data for the study were collected through a semi-structured interview schedule. Data from the study was analyzed by use of descriptive statistics to characterize the respondents on their socio-economic status such as educational level, fish farm experience, household size etc.

In ascertaining perceived effects of climate change on fish production, a three-point Likert-type scale was used and mean value of 2.0 accepted as effect. To obtain 
Table 2: Socio - economic Characteristics of Fish Farmers

\begin{tabular}{|c|c|c|}
\hline Parameters & Frequency & Percentage \\
\hline \multicolumn{3}{|l|}{ Aqe } \\
\hline $21-30$ & 31 & 12.4 \\
\hline $31-40$ & 54 & 31.6 \\
\hline $41-50$ & 60 & 24.0 \\
\hline 51 and above & 105 & 42.0 \\
\hline \multicolumn{3}{|l|}{ Sex } \\
\hline Male & 203 & 81.2 \\
\hline Female & 47 & 18.8 \\
\hline \multicolumn{3}{|l|}{ Marital status } \\
\hline Single & 25 & 10 \\
\hline Married & 207 & 82.8 \\
\hline Widow & 18 & 7.2 \\
\hline \multicolumn{3}{|l|}{ Household size } \\
\hline $1-5$ & 85 & 34 \\
\hline $6-10$ & 92 & 36.8 \\
\hline 11 and above & 73 & 29.2 \\
\hline \multicolumn{3}{|l|}{ Educational level } \\
\hline No formal education & 55 & 22.0 \\
\hline Primary & 78 & 31.2 \\
\hline Secondary & 94 & 37.6 \\
\hline Tertiary & 23 & 9.2 \\
\hline Fishing farming experience & 57 & 22.8 \\
\hline $1-10$ & 57 & 22.8 \\
\hline $11-20$ & 84 & 33.6 \\
\hline 21 and above & 109 & 43.6 \\
\hline \multicolumn{3}{|l|}{ Type of pond } \\
\hline Earthen pond & 104 & 41.6 \\
\hline Concrete pond & 45 & 18.0 \\
\hline Cage & 10 & 4.0 \\
\hline Home stead & 91 & 36.4 \\
\hline \multicolumn{3}{|l|}{ Fish farming system } \\
\hline Extension & 210 & 84.0 \\
\hline Semi intensive & 25 & 10.0 \\
\hline Intensive & 15 & 6.0 \\
\hline
\end{tabular}

responses from fish farmers on their observed evidence of climate change, a four-point Likert-type scale was used with mean value 2.50 accepted as observed evidence of climate change. To determine strategies adopted by fish farmers to reduce the effects of climate change, farmers were asked to choose from a list of various mitigation and adaptation options obtained from literature, expert opinions and observations (4). Data were analyzed using simple statistical tools such as frequency and percentages.

\section{RESULTS AND DISCUSSION}

\section{Socio-economic Characteristics of Respondents}

Table 2 shows the socio-economic characteristics of the respondents. The result reveals that $14.4 \%$ of the respondents were between 31 - 30 years, $21.6 \%$ were within $31-40$ years, $24 \%$ were within $41-51$ years, while $42 \%$ were 51 years and above age group. The implication here is that age of the respondent play an important role since it reveals one's knowledge and understanding of a phenomenon under study and other happenings in the society. Majority $(81.2 \%)$ of the respondents were men, while $18.8 \%$ were women. Men are family heads, husbands and fathers who own the farming business and takes vital decisions for the family. The table also shows that $82.8 \%$ of the respondents were married, $10 \%$ were single and $7.2 \%$ were widows.

On number of dependents, table 2 also shows that $34 \%$ had $1-5$ persons who depended on them, $36.8 \%$ had 6 - 10 persons depending on them and $29.2 \%$ that had 11 - people and above that depended on them. On education, $22 \%$ had no formal schooling, $31.2 \%$ had primary education, $37.6 \%$ had secondary education, only 
Table 3: Observed evidence of Climate CShange

\begin{tabular}{lcc}
\hline Scenario & Mean & Remarks \\
\hline Heavy rainfall & 4.45 & Serious \\
Increase precipitation & 3.50 & Serious \\
Reduced water precipitation & 2.50 & Serious \\
Change in rainfall pattern/time & 3.60 & Serious \\
Hot sunlight/sunshine & 4.50 & Serious \\
Heavy wind/waves & 4.70 & Serious \\
Longer period of hot season & 3.80 & Serious \\
Heavy flooding & 4.50 & Serious \\
Longer period of drought & 3.90 & Serious \\
\hline
\end{tabular}

about $9.2 \%$ had tertiary education. Education levels of an individual helps in knowledge acquisition and transfer. Agwu and Anyanwu (1996) reported that increase in educational status of farmers positively influence their perception and adoption of improved technologies and practices. Furthermore, majority $(43.6 \%)$ have been fishing for more than 21 years, $33.6 \%$ had put in $11-20$ years, while $22.8 \%$ had put in $1-10$ years. Earthen pond is common in the study area as indicated by $41.6 \%, 36 \%$ had homestead pond, $4 \%$ had cage, while $18 \%$ had concrete ponds. This also reveals the fish farming practices and pound type of the respondents. Others have cage pond for farming. Majority (84\%) rear fish extensively, $10 \%$ semi - intensive and intensive system (15\%) respectively.

\section{Observed Evidence of Climate Change by Respondents}

The respondents were fully aware of climate change as indicated by their responses. Table 3 showed the mean responses on the observed evidence of climate change. Heavy rainfall with mean response of 4.48, hot sunlight/sun shine $(M=4.50)$, heavy wind/waves $(M=$ 4.70), heavy flooding $(M=4.50)$, are all observed evidence of climate change. Other observe evidence are increase precipitation $(\mathrm{M}=3.50)$, reduced water precipitation $(M=3.60)$, longer periods of hot season $(M=$ $3.80)$, and longer periods of drought ( $M=3.90)$.

Supporting the above findings, IPCC (2007) reported that rising global temperature will rise, more water will evaporate from the oceans. Storms are expected to be more frequent and more intense in a warmer areas. Water evaporation will cause the soil to dry out faster between rains. Overall, higher latitudes are projected to receive rainfall, and subtropical areas aer projected to receive less. Shifting patterns of precipitation will occur. Droughts are projected to become longer and more intense. Again, Agbola and Ojeloye (2007) posited that the consequences of global warming include rise in the sea level and higher incident of tropical storms and, changes in agricultural production as a result of change in precipitation and other climate such as temperature and sunshine which affect crop production.

\section{Fish Farmers Perception of the Effects of Climate Change}

The effects of climate change on fish production could be positive as well as negative. Table 4 shows that climate change could lead to the following positive effects as indicated by the mean response, increased harvest of fish $(M=3.0)$, increased growth of fish $(M=3.0)$, increased productivity of some fish specie $(M=2.19)$, increased food conversion efficiency of aquatic resource $(M=2.3)$, long growing season $(M=2.30)$, fish range expansion due to heavy rainfall $(M=2.29)$, use of new areas due to ice cover decrease $(M=2.30)$. The negative effects of climate change on fish production are vulnerability of fish stock $(x=3.0)$, increaser cost of fish production $(M=3.0)$, food insecurity $(M=3.0)$, declining productivity $(M=3.0)$, and changes in fish harvest pattern $(x=3.0)$. other negative effects include loss of coral communities $(M=2.17)$, reduction of fish preproduction capacity $(M=2.60)$, increased fish disease outbreak $(M=$ $2.60)$, depletion of water resource $(M=2.14)$, reduced water quality $(x=2.45)$, decline death of indigenous fish species ( $M=2.60)$, occurrence of pollution $(M=2.11)$, reduced socio economic status of farmers $(M=2.30)$, ecological effects ( $M$ 2.48), and changes in employment opportunities $(\mathrm{M}=2.0)$.

\section{CONCLUSION}

Fish farmers in study area are fully aware of climate change scenarios as revealed by their responses to observed changes. The effects of climate change are both positive and negative. Climate change affects fish productivity and increases the cost of production, reduces reproductive capacity of fishes in hot temperatures and this leads to low productivity and food insecurity. 
Table 4: Fish farmers perception of positive and negative effects of climate change.

\begin{tabular}{lcc}
\hline Increased harvest of fish & 3.60 & $\mathrm{SE}$ \\
Increased productivity of some fish species & 2.19 & $\mathrm{SE}$ \\
Increased growth rate of fishes & 3.0 & $\mathrm{SE}$ \\
Increase food conversion efficiencies & 2.31 & $\mathrm{SE}$ \\
Longer growing season & 2.30 & $\mathrm{SE}$ \\
Fish range expansion due to heavy rains & 2.29 & $\mathrm{SE}$ \\
Use of new area due to ice cover decrease & 2.30 & $\mathrm{SE}$ \\
Areas of Negative Effect & & \\
Loss of coral communities & 2.17 & $\mathrm{SE}$ \\
Reduced fish reproductive capacity & 2.60 & $\mathrm{SE}$ \\
Fish stocks becomes vulnerable & 3.00 & $\mathrm{SE}$ \\
Increased fish diseases outbreak & 2.60 & $\mathrm{SE}$ \\
Increased cost of fish production & 3.00 & $\mathrm{SE}$ \\
Leads to food insecurity/hunger & 3.0 & $\mathrm{SE}$ \\
Depletion of water resources & 2.04 & $\mathrm{SE}$ \\
Reduced water quality & 2.45 & $\mathrm{SE}$ \\
Decline in indigenous fisher & 2.60 & $\mathrm{SE}$ \\
Depletion of water resources & 2.04 & $\mathrm{SE}$ \\
Reduced water quality & 2.45 & $\mathrm{SE}$ \\
Decline in indigenous fishers & 2.60 & $\mathrm{SE}$ \\
Decline in productivity of fish & 3.0 & $\mathrm{SE}$ \\
Occurrence of pollution & 2.11 & $\mathrm{SE}$ \\
Socio-economic status of fishers & 2.30 & $\mathrm{SE}$ \\
Ecological effects & 2.48 & $\mathrm{SE}$ \\
Changes in fish harvest pattern & 3.00 & $\mathrm{SE}$ \\
Changes in employment opportunities & 2.05 & $\mathrm{SE}$ \\
\hline
\end{tabular}

\section{REFERENCES}

Adebo GM, Ayelari TA (2011). Climate change and vunerability of fish farmers in Southwestern Nigeria African J. Agric Res 6(18): 42304238, 12 September, 2011

Agbola T, Ojeleye D (2007). Climate Change and Food Production in Ibadan, Nigeria. African Crop Science Conference Proceeding. 8: 1423-1433.

Agwu EA, Anyanwu AC (1996). Socio-cultural and Environmental Constraints in Implementing the NALDA Programme in South eastern Nigeria. Acase study of Abia and Enugu State. J. Agric. Educ, 2: 68-72.

Akinrotimi OA, Edum OM, Uka A, Ogori KT, Mokayi PK, Orokotan OO (2007). The Role of Fish in the Nutrition and Livelihood of Families In Niger Delta, Nigeria. Int. J. Trop. Agric. Food Syst. 1: 344-351

Ezenwa BIO (2004). Aquaculture Development Research In Nigeria. In Cohe, G. (Ed) Aquaculture Development And Research In subSaharan Africa. Food And Agriculture Organization, Rome

IPCC (2007a) Climate Change 2007: Synthesis Report - Contribution of Working Groups I, II, and III to the Fourth Intergovernmental Panel on Climate Change. Core Writing Team: R.K. Pauchauri and A. Reisinger, eds. IPCC, Geneva, Switzerland. 8:

NEPAD (2005). The NEPAD Action Plan for the Development of African Fisheries and TheAquaculture. Proceedings of The NEPAD- Fish for All Summit, August 22-25, Abuja
Prowse M, Grist N, Sourang C (2009). Closing the gap between climate adaptation and poverty reduction frameworks. Project Briefing No. 21. Overseas Development Institute, London, UK, 4 pp. Available at: http://www.odi.org.uk/resources/download/3290.pdf. Date accessed: 6 December 2010.

RSADP (2000). Rivers State Agricultural Development Programme Annual Report. Rivers State Ministry of Agriculture, Nigeria $36 \mathrm{pp}$

Satia BP (1990). National Reviews For Aquaculture Development In Africa; Nigeria Report No C770.29 FAO-Fisheries Circular No 770.29 FAO, Rome

UNEP-WCMC (2006). In the Front Line: Shoreline protection and other ecosystem services from mangroves and coral reefs. UNEP-WCMC, Cambridge, UK, 33 pp. Available at: http://data.iucn.org/dbtwwpd/edocs/2006-025.pdf. Date accessed: 6 December 2010

Walther G, Post E, Convey P et al. (2002). Ecological responses to recent climate change. Nature 416: 389-395. 